\section{AB0690 CLINICAL EXPERIENCE WITH INFLIXIMAB BIOSIMILAR (BOW015) IN ANKYLOSING SPONDYLITIS- EFFICACY AND SAFETY ANALYSIS FROM AN INDIAN PERSPECTIVE}

I. Agrawal ${ }^{1}$, A.N. Roy ${ }^{2}$, R. Kiran ${ }^{3}$, V.K. Rao ${ }^{4}$, R.N. Sarkar ${ }^{5}$, S. Naorem ${ }^{6}$, A. Ray ${ }^{7}$, M. Shamil ${ }^{8} .{ }^{1}$ Department of Rheumatology, Paras Hospital, Delhi; ${ }^{2}$ Department of Rheumatology, Yashoda Hospital; ${ }^{3}$ Department of Rheumatology, Star Hospital, Hyderabad; ${ }^{4}$ Department of Rheumatology, Manipal Hospital, Bengaluru; ${ }^{5}$ Department of Rheumatology, Medical college of Kolkata, Kolkata; ${ }^{6}$ Department of Medicine, Regional Institute of Medical Sciences, Imphal; ${ }^{7}$ Department of Rheumatology, Radiant Medical Centre, Kolkata; ${ }^{8}$ Medical Affairs Manager, Sun Pharma Laboratories Ltd, Mumbai, India

Background: The regulatory phase III trial supporting the approval of biosimilar infliximab (BOW015) in India included only rheumatoid arthritis patients. Consequently there is paucity of data on the effectiveness of BOW015 in Ankylosing Spondylitis (AS)..$^{1,2,3}$ Hence, we decided to objectively quantify the effectiveness and safety of BOW015 in AS patients.

Objectives: To determine safety, efficacy and tolerability of BOW015 in Indian AS patients.

Methods: We retrospectively collected data from seven centres to get a comprehensive picture of the Indian population. The protocol along with data collection form was designed by the investigators and ethics committee approval was obtained. Biologic naïve patients diagnosed with AS as per Assessment of Spondylo Arthritis International Society criteria who were having six months of follow up data during January-November 2016 were included in the study. Percentage of patients achieving major clinical improvement (Ankylosing Spondylitis Disease Activity Score C-reactive protein $\left(\operatorname{ASDAS}_{C R P}\right)>2$ from the baseline to six months of follow up) was the primary variable. Secondary variables included; clinical improvement criteria (ASDAS $\mathrm{CRP}>1.1$ from the baseline to six months of follow up), change in ASDAS (BASDAI), CRP and Erythrocyte Sedimentation Rate (ESR) from the baseline to six months. Variables were reported as mean \pm Standard Deviation (SD), absolute change in variable were reported along with their Confidence Interval $(\mathrm{Cl})$ and data was analyzed using Statistical Package for the Social Science V-22.

Results: A total of 68 patients treated with BOW015 having follow-up data for six months were analyzed. Mean age of patients was $32.63 \pm 11.73$ (SD) years with mean body mass index of $25.72 \pm 7.48$ (SD) $\mathrm{kg} / \mathrm{m}^{2}$ and about $32(47 \%)$ patients had peripheral arthritis. Of the treated patients, $52(76 \%)$ patients were administered four doses while $6(9 \%)$ patients administered three doses, 3 $(5 \%)$ patients administered two doses and $7(10 \%)$ patients administered single dose as they were loss to follow up. As per the primary variable, $67.9 \%$ patients achieved major clinical improvement, 9.4\% patients achieved clinical improvement and $22.6 \%$ were non-responders. There was an absolute change of $-2.54(95 \%$ $\mathrm{Cl}-1.92,-3.17)$ in BASDAl and $-1.77(95 \% \mathrm{Cl}-1.43,-2.11)$ in ASDAS $_{\mathrm{CRP}}$ right from first follow up corresponding to post 1 st dose visit which was statistically significant (see Table-1). This trend was observed in the subsequent visits in BASDAI, ASDAS ${ }_{C R P}, E S R$ and CRP which continued till the end of six months. One patient developed pulmonary tuberculosis and marginally elevated liver enzymes were seen in two patients.

Table 1: Change in the primary and secondary variables

\begin{tabular}{|c|c|c|c|c|c|}
\hline & $\begin{array}{l}\text { Baseline } \\
\text { (meantSD }\end{array}$ & $\begin{array}{l}\Delta \text { Baseline to } \\
1^{\text {st }} \text { follow up } \\
\text { (Mean } \\
\text { Difference; } 95 \% \\
\text { CI) }\end{array}$ & $\begin{array}{l}\Delta \text { Baseline to } \\
2^{\text {nd }} \text { follow up } \\
\text { (Mean } \\
\text { Difference; } \\
95 \% \mathrm{CI} \text { ) }\end{array}$ & $\begin{array}{l}\Delta \text { Baseline to } \\
6 \text { months } \\
\text { follow up } \\
\text { (Mean } \\
\text { Difference; } \\
95 \% \mathrm{CI} \text { ) }\end{array}$ & $\begin{array}{l}\text { P value } \\
\text { compared } \\
\text { to previous } \\
\text { visit and } \\
\text { baseline vs. } \\
6 \text { months } \\
\text { FU }\end{array}$ \\
\hline BASDAI & $5.83 \pm 1.90$ & $\begin{array}{c}-2.54 \\
(95 \% \text { CI }-1.92,- \\
3.17)\end{array}$ & $\begin{array}{c}-3.44 \\
(95 \% \text { CI }-2.79, \\
-4.09)\end{array}$ & $\begin{array}{c}-3.77 \\
(95 \% \text { CI }-3.05,- \\
4.48)\end{array}$ & $<0.05$ \\
\hline $\begin{array}{l}\operatorname{ASDAS}_{\mathrm{C}} \\
\mathrm{RP}\end{array}$ & $3.88 \pm 0.80$ & $\begin{array}{c}-1.77 \\
(95 \% \text { CI }-1.43,- \\
2.11)\end{array}$ & $\begin{array}{c}-2.212 \\
(95 \% \mathrm{CI}-1.86, \\
-2.55)\end{array}$ & $\begin{array}{c}-2.13 \\
(95 \% \text { CI }-1.78,- \\
2.47)\end{array}$ & $<0.05$ \\
\hline $\begin{array}{l}\text { ESR } \\
(\mathrm{mm} / \mathrm{h})\end{array}$ & $\begin{array}{c}39.45 \pm 27.0 \\
4\end{array}$ & $\begin{array}{c}-20.82 \\
(95 \% \text { CI }-14.08, \\
27.55)\end{array}$ & $\begin{array}{c}-26.137 \\
(95 \% \mathrm{CI}- \\
19.05,-33.22)\end{array}$ & $\begin{array}{c}-26.087 \\
(95 \% \text { CI - 17.89, } \\
34.28)\end{array}$ & $<0.05$ \\
\hline $\begin{array}{l}\text { CRP( } \\
\mathrm{mg} / \mathrm{L})\end{array}$ & $\begin{array}{c}25.06 \pm 22.8 \\
4\end{array}$ & $\begin{array}{c}-18.408 \\
(95 \% \text { CI -12.01, } \\
24.80)\end{array}$ & $\begin{array}{c}-18.918 \\
(95 \% \mathrm{CI}- \\
12.69,-25.14)\end{array}$ & $\begin{array}{c}-15.702 \\
(95 \% \text { CI }-9.38, \\
22.02)\end{array}$ & $<0.05$ \\
\hline
\end{tabular}

Conclusions: BOW015 showed significant improvement in ASDAS CRP $_{\text {and }}$ BASDAI in patients with AS on a six month follow up period and the clinical benefits were apparent as early as first dose of BOW015.

\section{References:}

[1] Kay J et al. Ann Rheum Dis 2014; 73(Suppl2):64.

[2] Kay J et al. Arthritis Rheumatol. 2014; 66(12):3538.

[3] Dörner T, Kay J. Biosimilars in rheumatology: current perspectives and lessons learnt. Nat Rev Rheumatol. 2015 Dec;11(12):713-24.

Disclosure of Interest: I. Agrawal: None declared, A. Roy: None declared, R. Kiran: None declared, V. Rao: None declared, R. Sarkar: None declared, S. Naorem: None declared, A. Ray: None declared, M. Shamil Employee of: Sun Pharma Laboratories Ltd, Mumbai, India

DOI: 10.1136/annrheumdis-2017-eular.5865
AB0691 METFORMIN THERAPY CAN RESTORE THE BALANCE OF TH17 AND TREG CELLS IN PATIENTS WITH SPONDYLOARTHRIT

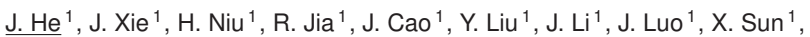
X. Li ${ }^{1}, \mathrm{C} . \mathrm{Lu}^{2}, \mathrm{C} . \mathrm{Gao}^{3} .{ }^{1}$ Rheumatology, The Second Hospital of Shanxi Medical University, Taiyuan; ${ }^{2}$ Rheumatology, West China Hospital of Sichuan Universit, Sichuan, China; ${ }^{3}$ Pathology, Brigham and Women's Hospital, Harvard Medical School, Boston, United States

Background: Spondyloarthrit $(\mathrm{SpA})$ is a chronic autoimmune disease and is associated with immunological function disorder. Previous studies have observed that increased number of T17 cells and decreased number of Regulatory T (Treg) cell in patients with $S[1,2]$. However, the current therapy for $\mathrm{SpA}$, focusedon NSAID, biological agents and glucocorticoid, can't correct the imbalance of Th17 and Treg cells. Metformin has been demonstrated a reducing effect on Th17 cells but an increasing effect on Treg cells, regulating the Thl7/Treg ratio [3].

Objectives: The study is to explore the effect of metformin therapy on the balance of Th17 and Treg cells in patients with SpA.

Methods: SpA patients $(n=27$ ) (from August 1st to November 30th in 2016, both outpatients and inpatients in our department, according to American-European Consensus Group criteria for SpA), who were given metformin (750mg/day for 6 weeks). Laboratory indicators were compared before and after metformin treatment.

Results: The number of Treg cells [25.37 (18.31,45.78) vs.34.43 (25.91,50.31), $\mathrm{P}=0.015]$ significantly increased after the treatment. At the same time, there was a significantly decrease in the ratio of Th17/Treg cells $[0.26(0.15,0.48)$ vs. 0.22 $(0.1,0.33), P+0.037]$. Besides, Th17 cells were also decreased $[7.85(4.95,10.65)$ vs. $6.42(3.7,10.63)]$

Conclusions: Metformin can restore and maintain the balance of Th17 and Treg cells in the patients with SpA. And it may be a potential therapy for SpA.

\section{References:}

[1] Jandus C, Bioley G, Rivals JP, Dudler J, Speiser D, Romero P. Increased numbers of circulating polyfunctional Th17 memory cells in patients with seronegative spondylarthritides.Arthritis Rheum. 2008;58:2307-17.

[2] Shen H, Goodall JC, Hill Gaston JS. Frequency and phenotype of peripheral blood Th17 cells in ankylosing spondylitis and rheumatoid arthritis. Arthritis Rheum. 2009;60:1647-56.

[3] Son HJ, Lee J. Metformin attenuates experimental autoimmune arthritis through reciprocal regulation of Th17/Treg balance and osteoclastogenesis. Mediators Inflamm.2014,2014:973986.

Disclosure of Interest: None declared

DOI: 10.1136/annrheumdis-2017-eular.4554

\section{AB0692 EFFECTS OF INTRAVENOUS GOLIMUMAB ON PATIENT-REPORTED OUTCOMES IN ACTIVE ANKYLOSING SPONDYLITIS: 28-WEEK RESULTS OF THE PHASE III GO-ALIVE TRIAL}

J.D. Reveille ${ }^{1}$, A. Deodhar ${ }^{2}$, E.K. Chan ${ }^{3}$, S. Peterson ${ }^{4}$, N. Li ${ }^{4}$, E. Hsia ${ }^{4,5}$ L. Kim ${ }^{4}$, K.H. Lo ${ }^{4}$, D.D. Harrison ${ }^{4}$, C. Han ${ }^{6} .{ }^{1}$ University of Texas Health Sciences Center, Houston; ${ }^{2}$ Oregon Health \& Science University, Portland; ${ }^{3}$ Janssen Global Services, LLC, Raritan; ${ }^{4}$ Janssen R\&D, LLC, Spring House; ${ }^{5}$ University of Pennsylvania School of Medicine, Philadelphia; ${ }^{6}$ Janssen Global Services, LLC, Malvern, United States

Objectives: To evaluate patient-reported outcomes (PRO) of physical functioning mental health functioning, health state, and health-related quality of life (HRQoL) in patients (pts) w/active Ankylosing Spondylitis (AS) treated w/intravenously administered (IV) golimumab (GLM), an anti-TNF $\alpha$ monoclonal antibody.

Methods: GO-ALIVE is a Phase 3, multicenter, randomized, double-blind, placebo-controlled trial. Pts (aged $\geq 18$ years) had a diagnosis of definite AS (pe modified New York criteria) and BASDAI $>4$, total back pain visual analogue scale $\geq 4$, and CRP $\geq 0.3 \mathrm{mg} / \mathrm{dL}$. At baseline, $208 \mathrm{pts}$ were randomized either to IV GLM $2 \mathrm{mg} / \mathrm{kg}(\mathrm{N}=105)$ at Wks 0,4 , and every 8 wks or placebo (PBO, $\mathrm{N}=103)$ at Wks 0,4 , and $12, \mathrm{w} /$ crossover to GLM at Wk 16 .

Three PRO instruments were included: 1) SF-36, a generic instrument designed to measure physical \& mental health functioning, 2) EQ-5D visual analogue scale (VAS), a generic measure of current health state \& 3) Ankylosing Spondylitis Quality of Life (ASQoL) questionnaire, a disease-specific instrument designed to measure the impact of AS on HRQoL. The scores for SF-36 range from 0-100 w/higher scores indicating better functioning. It has Physical (PCS) and Mental Component Summary (MCS) and eight subscales (physical functioning, role-physical, body pain, general health, vitality, social functioning, role-emotional, \& mental health). EQ-5D has a scale of $0-100(0=$ worst health you can imagine to $100=$ best health you can imagine). ASQoL assesses sleep, mood, motivation, ability to cope, activities of daily living, independence, relationships, \& social life in pts w/AS. The scores range from 0-18 w/higher scores indicating worse HRQoL. Unadjusted p-values of least square mean differences (LSMD) between treatment groups were based on analysis of covariance (ANCOVA) controlling for prior anti-TNF therapy.

Results: Table 1 summarizes the mean changes from baseline at Wks 8,16 \& 28. Improvements from baseline in SF-36 PCS \& MCS were greater in the GLM group than PBO at Wk 8 (6.83 vs. $2.07, p<0.001 ; 5.56$ vs. $1.67, p=0.006$, respectively) and maintained through Wk 16 (8.52 vs. $2.87, \mathrm{p}<0.001 ; 6.47$ vs 